\title{
Monitoring Potential Transport of Radioactive Contaminants in Shallow Ephemeral Channels
}

\author{
prepared by \\ Julianne J. Miller, Steve A. Mizell, \\ George Nikolich, and Scott A. Campbell \\ Desert Research Institute \\ Nevada System of Higher Education
}

submitted to

Nevada Site Office

National Nuclear Security Administration

U.S. Department of Energy

Las Vegas, Nevada

February 2012

\section{Publication No. 45242}


Reference herein to any specific commercial product, process, or service by trade name, trademark, manufacturer, or otherwise, does not necessarily constitute or imply its endorsement, recommendation, or favoring by the United States Government or any agency thereof or its contractors or subcontractors.

Available for sale to the public from:

\section{U.S. Department of Commerce}

National Technical Information Service

5301 Shawnee Road

Alexandria, VA 22312

Phone: 800.553.6847

Fax: 703.605.6900

Email: orders@ntis.gov

Online ordering: http://www.osti.gov/ordering.htm

Available electronically at htp://www.osti.gov/bridge

Available for a processing fee to the U.S. Department of Energy and its contractors, in paper, from:

U.S. Department of Energy

Office of Scientific and Technical Information

P.O. Box 62

Oak Ridge, TN 37831-0062

Phone: 865.576.8401

Fax: 865.576.5728

Email: reports@adonis.osti.gov 


\title{
Monitoring Potential Transport of Radioactive Contaminants in Shallow Ephemeral Channels
}

\author{
prepared by \\ Julianne J. Miller, Steve A. Mizell, \\ George Nikolich, and Scott A. Campbell \\ Desert Research Institute \\ Nevada System of Higher Education
}

Publication No. 45242

submitted to

Nevada Site Office

National Nuclear Security Administration

U.S. Department of Energy

Las Vegas, Nevada

February 2012

\footnotetext{
The work upon which this report is based was supported by the U.S. Department of Energy under Contract \#s DE-AC52-06NA26383 and DE-NA0000939. Approved for public release; further dissemination unlimited.
} 
THIS PAGE INTENTIONALLY LEFT BLANK 


\section{CONTENTS}



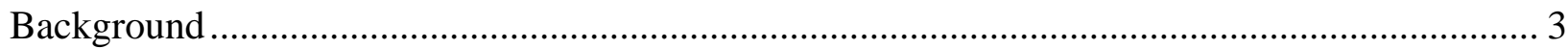

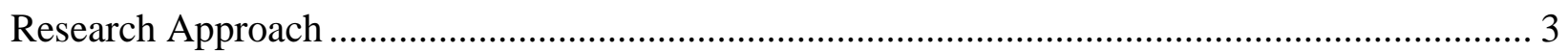

Future Work .

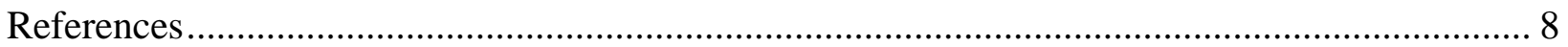

\section{LIST OF FIGURES}

1. Americium-241 detections at the Smoky CA in northwest Yucca Flat, Nevada (Colton, 1999).

2. Approximate locations of the meteorological station and flume installations at the Smoky CA in Yucca Flat, Nevada National Security Site, are shown.

3. Smoky CA meteorological station was installed to measure precipitation and wind and other climate parameters.

4. View looking downstream through the flume installed to measure runoff from the Smoky CA.

5. Runoff conditions in the flume are detected by pressure transducer (yellow cable), recorded in the datalogger (white box) and relayed by radio (black antenna) to the meteorological station for transmission to the Western Regional Climate Center via GOES satellite.

6. Changes in the downstream edge of the white sand and painted pebble bands will be made to quantify sediment movement during recorded runoff events.

$\begin{array}{ll}\text { Am-241 } & \text { Americium-241 } \\ \text { CA } & \text { Contamination Area } \\ \text { CAS } & \text { Corrective Action Site } \\ \text { CAU } & \text { Corrective Action Unit } \\ \text { DOE } & \text { Department of Energy } \\ \text { DRI } & \text { Desert Research institute } \\ \text { GOES } & \text { Geostationary Operational Environmental Satellite } \\ \text { NNSS } & \text { Nevada National Security Site } \\ \text { WRCC } & \text { Western Regional Climate Center }\end{array}$


THIS PAGE INTENTIONALLY LEFT BLANK 


\section{INTRODUCTION}

The U.S. Department of Energy (DOE) National Nuclear Security Administration (NNSA), Nevada Site Office (NSO), Environmental Restoration Soils Activity has authorized the Desert Research Institute (DRI) to conduct field assessments of potential sediment transport of contaminated soil from Corrective Action Unit (CAU) 550, Area 8 Smoky Contamination Area (CA), during precipitation runoff events. CAU 550 includes Corrective Action Sites (CASs) 08-23-03, 08-23-04, 08-23-06, and 08-23-07; these CASs are associated with tests designated Ceres, Smoky, Oberon, and Titania, respectively.

Field measurements at the T-4 Atmospheric Test Site, CAU 370, suggest that radioactive material may have migrated along a shallow ephemeral drainage that traverses the site (NNSA/NSO, 2009). (It is not entirely clear how contaminated soils got into their present location at the T-4 Site, but flow to the channel has been redirected and the contamination does not appear to be migrating at present.) Although DRI initially looked at the CAU370 site, given that it could not be confirmed that migration of contamination into the channel was natural, an alternate study site was selected at CAU 550. Aerial surveys in selected portions of the Nevada National Security Site (NNSS) also suggest that radioactivity may be migrating along ephemeral channels in Areas 3, 8, 11, 18, and 25 (Colton, 1999).

Figure 1 shows the results of a low-level airborne survey (Colton, 1999) in Area 8. The numbered markers in Figure 1 identify ground zero for three safety experiments conducted in 1958 [Oberon (number 1), Ceres (number 2), and Titania (number 4)] and a weapons effects test conducted in 1964, Mudpack number (3). This survey suggests contaminants may be migrating down the ephemeral channels that traverse CAU 550. Note particularly the lobe of higher concentration extending southeastward at the south end of the high concentration area marked as number 3 in Figure 1.

CAU 550 in Area 8 of the NNSS was selected for the study because the aerial survey indicates that a channel mapped on the U.S. Geological Survey topographic map of the area traverses the south end of the area of surface contamination; this channel lies south of the point marked number 3 in Figure 1, and anecdotal information indicates that sediment has been deposited on the road bordering the southeast boundary of the CAU from an adjacent channel (J. Traynor, personal communication, 2011). Because contamination is particularly close to the boundary of CAU 550, Smoky CA, it is important to know if contaminants are moving, what meteorological conditions result in movement of contaminated soils, and what particle size fractions associated with contamination are involved.

Closure plans are being developed for the CAUs on the NNSS. The closure plans may include post-closure monitoring for possible release of radioactive contaminants. Determining the potential for transport of contaminated soils under ambient climatic conditions will facilitate an appropriate closure design and post-closure monitoring program. 

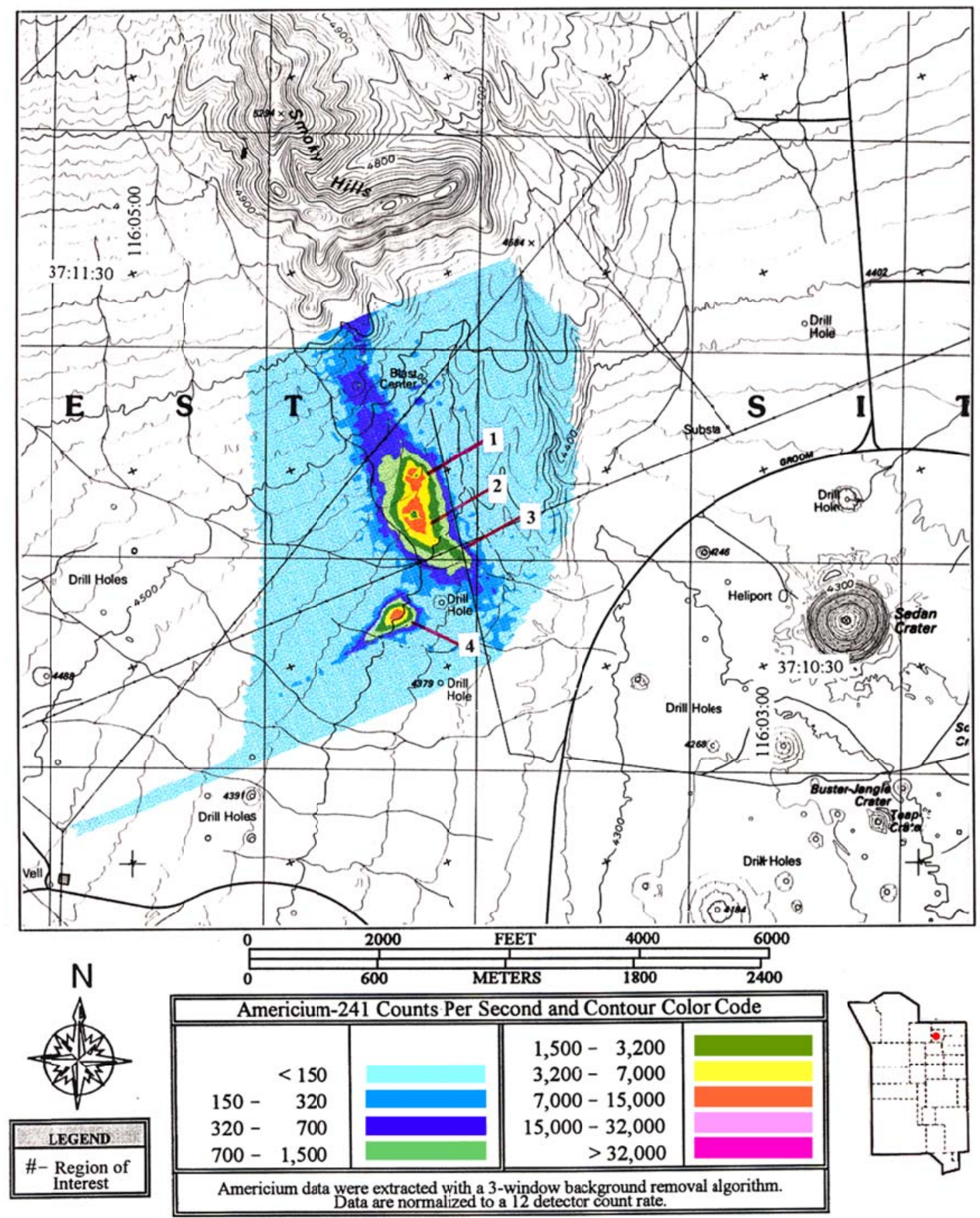

Figure 1. Americium-241 detections at the Smoky CA in northwest Yucca Flat, Nevada (Colton, 1999). 


\section{BACKGROUND}

The Smoky CA is located in Area 8 of the NNSS in northern Yucca Flat, southeastern Nye County, Nevada. In addition to the namesake test, Smoky, an above ground nuclear device test detonated in 1957, four additional tests were conducted in the area; these include three safety tests (Oberon, Ceres, and Titania) conducted in 1958 and a weapons effect test, Mudpack, conducted in 1964 (Colton, 1999). As a result of these tests there is an elongated area of surface contamination trending in a northwest-southeast direction (Colton, 1999). This area of surface contamination encompasses the Smoky, Oberon, Ceres, and Mudpack test locations. Near the southern extent, and slightly to the southwest, of this contamination area is a triangular shaped area of surface contamination associated with the Titania test. A low-level aerial survey of the area (Figure 1) reported up to 15,000 counts per second Am-241 at the center of the two surface contamination areas (Colton, 1999). Additionally, there has been measured contamination transported across Circle Road from an adjacent channel (J. Traynor, personal communication, 2011).

The Smoky CA is situated on the alluvial fan approximately 0.3 miles $(1,000 \mathrm{~m})$ south of the Smoky Hills. Mapped drainages shown on the Oak Spring, Nevada topographic map (U.S. Geological Survey 1:24000 scale) trend south-southeast from the Smoky Hills then easterly toward the center of Yucca Flat. The larger of the two contaminated areas in the Smoky CA is bounded on the east, west and south by mapped channels. The western corner of the smaller contamination area surrounding the Titania test is drained by a mapped channel trending west to east. Elevation contours in the immediate vicinity of these contamination areas suggest unmapped channels may convey runoff from the areas of highest contamination into the mapped drainages.

\section{RESEARCH APPROACH}

The presence of radionuclide- contaminated soils in channels that traverse and convey runoff from the Smoky CA suggests that contaminated soil has been transported by rainfallrunoff. However, there is insufficient data to determine if the observed contamination is the result of an ongoing process or if the transport was limited to a period of higher hydraulic energy resulting from reduced ground cover immediately following the Smoky area tests.

Desert Research Institute proposed to perform a field scale assessment of meteorological and hydrologic conditions that would potentially lead to transport of radionuclide-contaminated soil from the Smoky CA. The research plan includes measurement of local meteorological parameters, measurement of runoff resulting from local rainfall, and visual observation of marked soil particle migration associated with rainfall-runoff. Measurements will be made at locations in and adjacent to the Smoky CA (Figure 2). The precipitation and runoff data will be used to establish threshold conditions that would likely lead to transport of soil particles, including radionuclide-contaminated soils. Such thresholds will aid establishment of conditions 
that cause monitoring of drainage channel transport pathways to be implemented under a future closure plan.

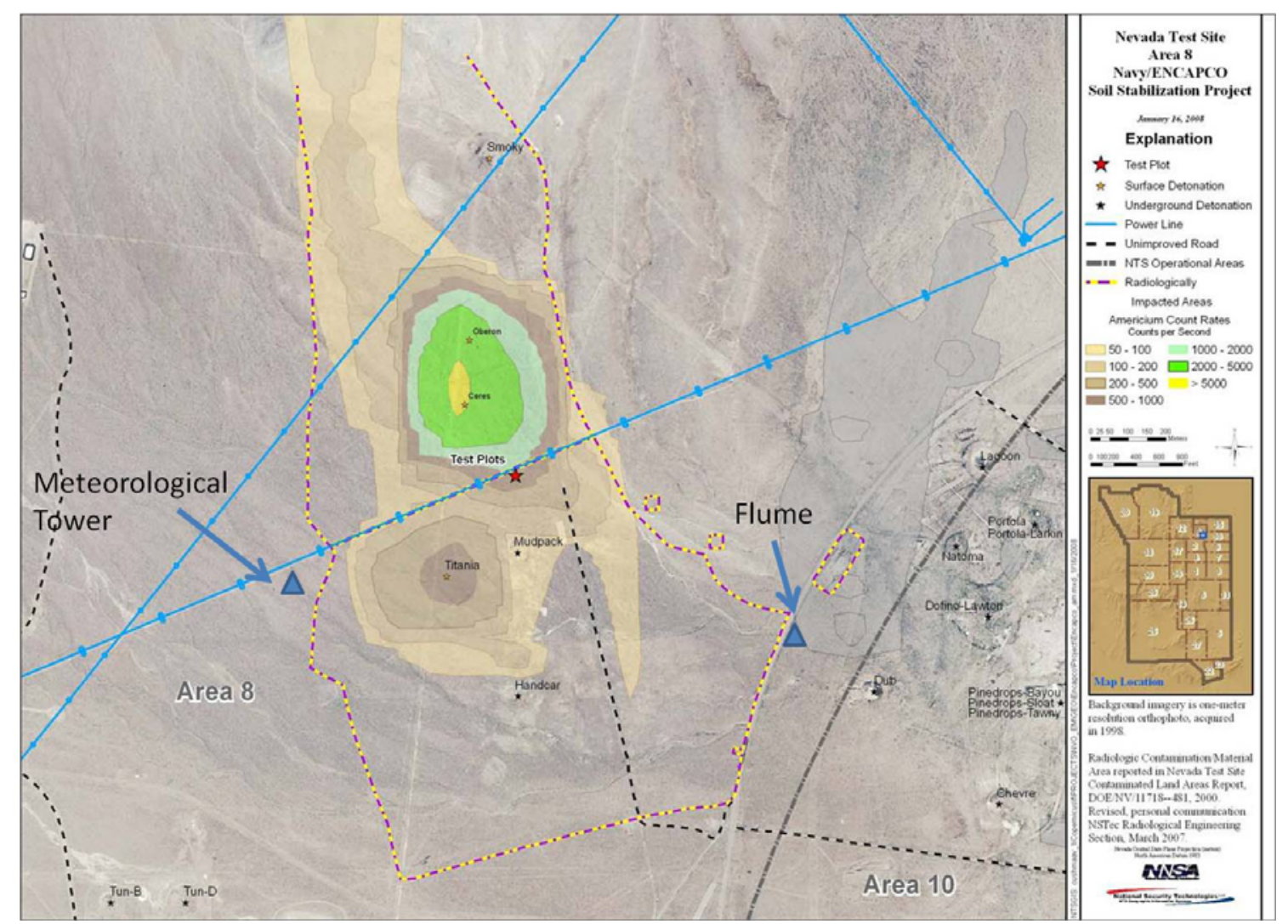

Figure 2. Approximate locations of the meteorological station and flume installations at the Smoky CA in Yucca Flat, Nevada National Security Site, are shown.

The meteorological (met) station, including instrumentation to measure temperature, relative humidity, wind speed, wind direction, soil volumetric-water content, soil temperature, solar radiation, barometric pressure and precipitation, was installed in an uncontaminated area adjacent to the Smoky CA (Figure 2 and 3) on July 14 and 15, 2011. Coordinates of the meteorological station are $37^{\circ} 10^{\prime} 39.48$ ” latitude and $-116^{\circ} 4^{\prime} 25.59^{\prime}$ longitude. The meteorological station also includes Geostationary Operational Environmental Satellite (GOES) transmission equipment and equipment to receive radio frequency data transmissions from the flume installation (Figure 2). Accumulated meteorological data is transmitted to the Western Regional Climate Center (WRCC) at the DRI offices in Reno at regularly scheduled intervals. At the WRCC the data will be uploaded to a restricted access internet web page available to project personnel.

A flume to measure channelized runoff was originally to be installed between the Smoky CA boundary and the adjoining road (Figure 2). However, because there was not sufficient space on the shoulder of the road and because Radiological Control determined that it was not possible 
to downgrade contamination controls on the study channel to be instrumented, the flume (Figure 2 and 4) was placed inside the Smoky CA. Flume was installation on July 19, 2011 at a

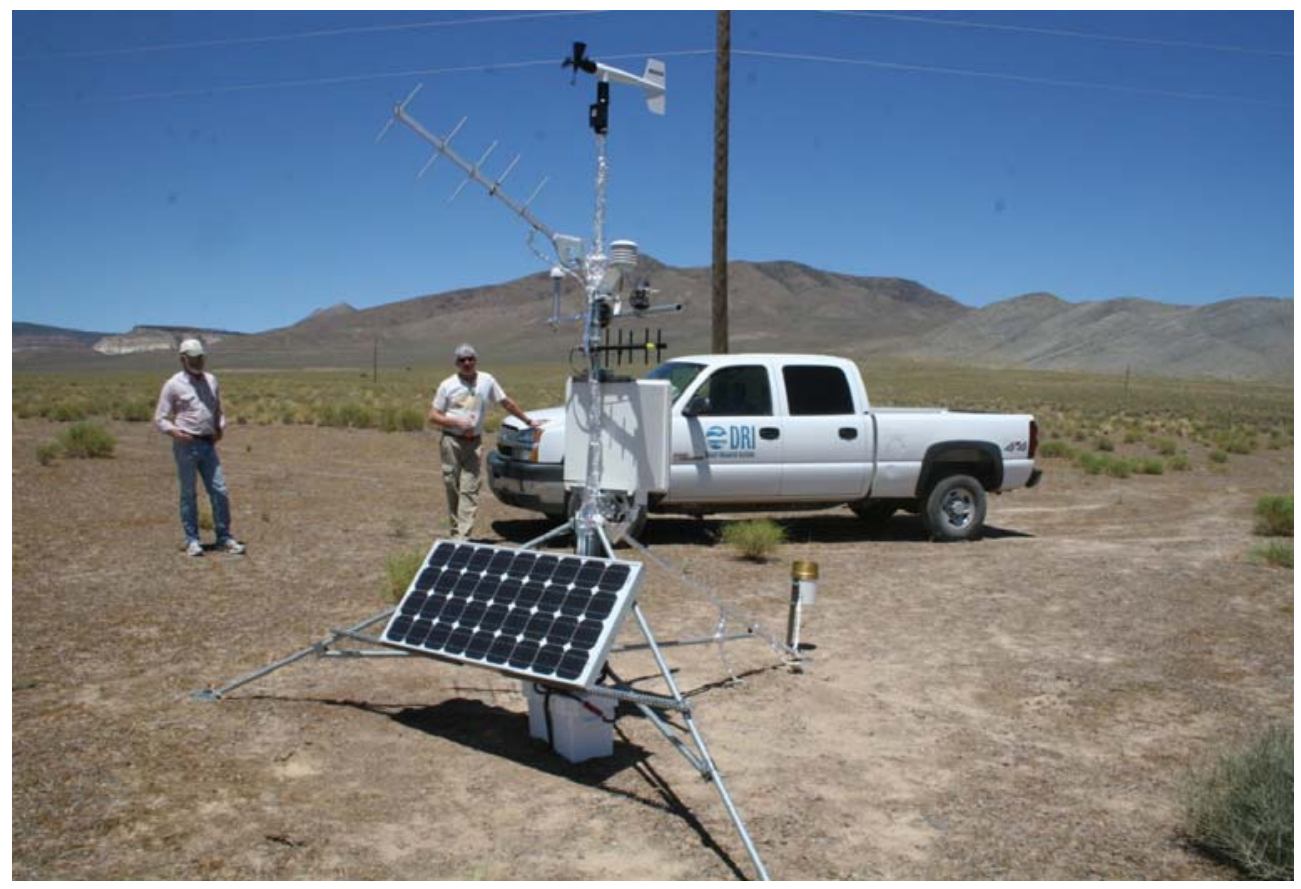

Figure 3. Smoky CA meteorological station was installed to measure precipitation and wind and other climate parameters.

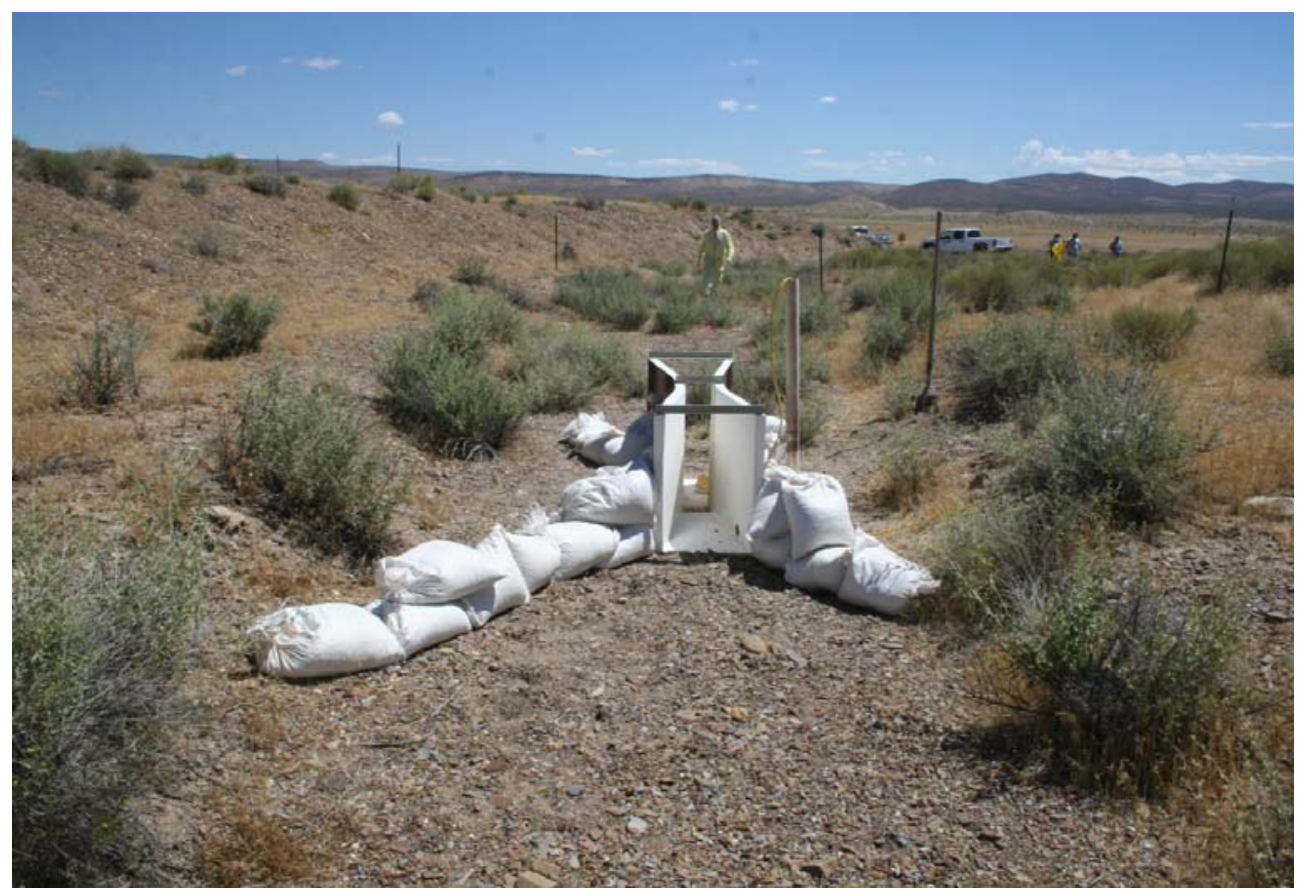

Figure 4. View looking downstream through the flume installed to measure runoff from the Smoky CA. 
location approximately $50 \mathrm{ft}(15 \mathrm{~m})$ upstream of the position indicated in Figure 2. Coordinates of the flume are $37^{\circ} 10^{\prime} 37.13^{\prime \prime}$ latitude and $-116^{\circ} 3$ ' $34.85^{\prime \prime}$ longitude. The flume installation includes a pressure transducer for measuring depth of flow through the flume and a radio frequency transmitter/receiver to permit communication with the met station (Figure 5).

White silica sand and painted river pebbles (Figure 6) were installed in the drainage channel upstream of the flume on July 19, 2011 to permit visual observation of sediment movement in the channel bed. Because it was not possible to downgrade the radiological control on the study channel, measurement of marked particle migration will be limited to times when casual observation suggests migration has occurred or entry to the CA is required to service the flume equipment.

Meteorological and flume data transmissions from the Smoky CA were received beginning July 20, 2011. Reported measurements indicate that all instrumentation is functioning properly.

\section{FUTURE WORK}

Data transmitted from the Smoky CA instrumentation will be reviewed monthly by project personnel to identify precipitation events that exceed the specified rainfall threshold $(\sim 0.2$ inches $[0.5 \mathrm{~cm}])$ and to assess proper operation of the instrumentation and remote communication equipment. Field inspections will be scheduled to service instrumentation if necessary.

Meteorological data collected leading up to and during a detected runoff event will be analyzed to characterize the meteorological conditions that produced the runoff. This analysis will help delineate threshold conditions that are likely to result in sediment transport and migration of radionuclides in conjunction with the sediment. Establishment of these thresholds will aid identification of meteorological conditions that may require monitoring and sampling of channel runoff migration pathways under a closure plan. Requirements for monitoring meteorological conditions and for sampling runoff pathways can then be appropriately incorporated in closure plans.

During site visits to service instrumentation, the migration of marked soil particles will be noted to generate a qualitative response of soil migration in response to accumulated rainfallrunoff events. Bedload samples will be collected downstream of the flume following measurable rainfall-runoff events to determine the size of soil material moved and the concentration of radionuclides, if any, associated with the migrating sediment.

Because they are located inside the CA, any service work on the flume or data logger and communication equipment associated with the flume will require Radiological Control Technician support. 


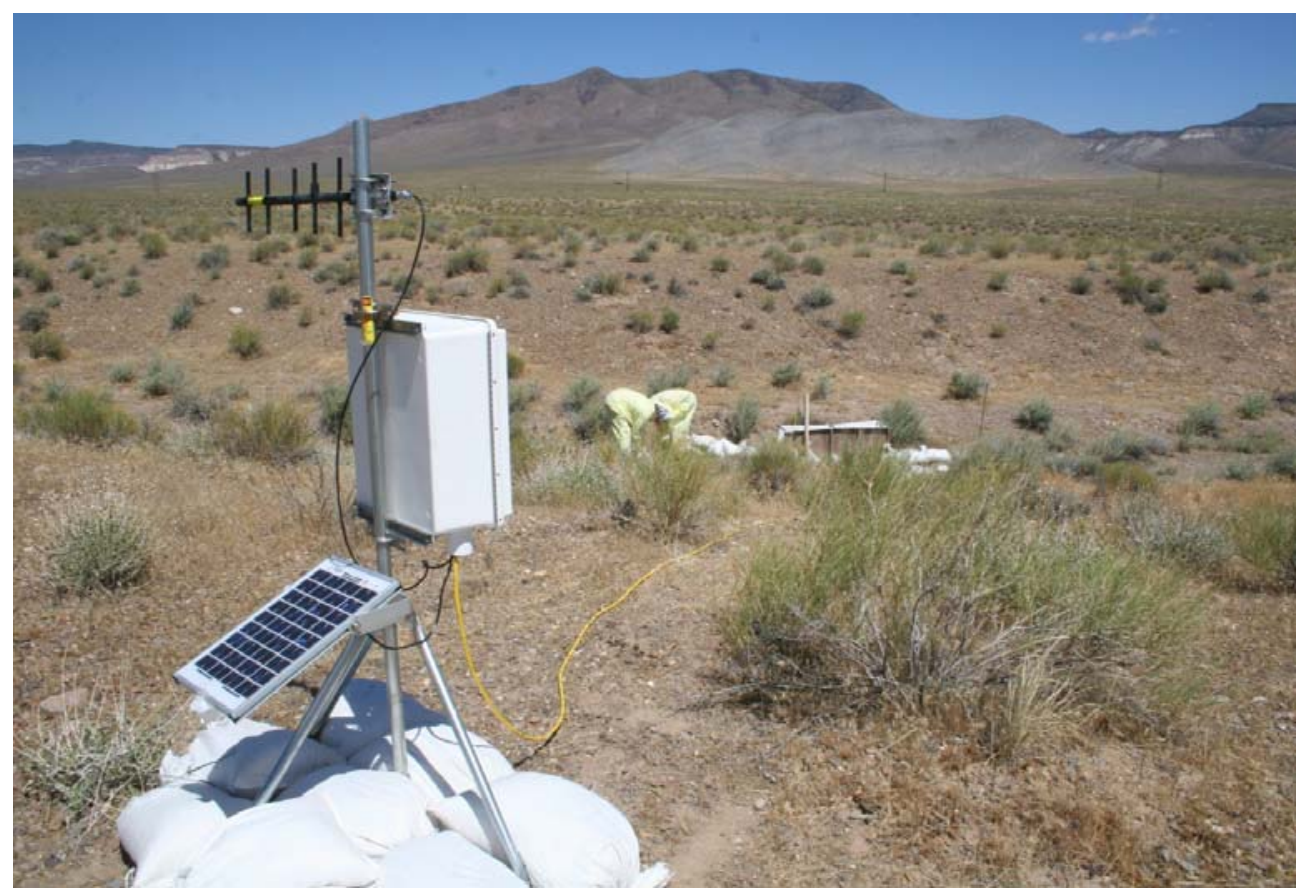

Figure 5. Runoff conditions in the flume are detected by pressure transducer (yellow cable), recorded in the datalogger (white box) and relayed by radio (black antenna) to the meteorological station for transmission to the Western Regional Climate Center via GOES satellite.

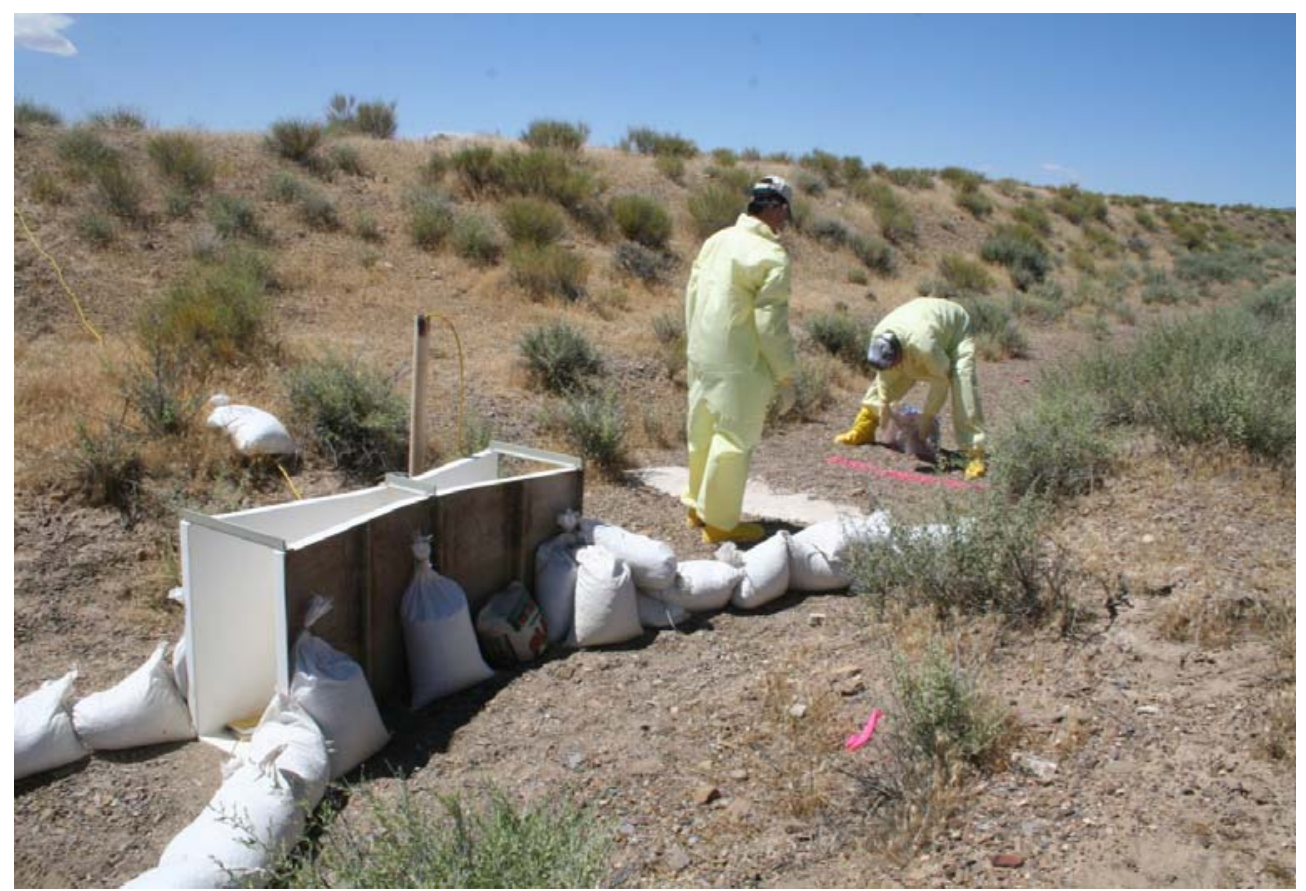

Figure 6. Changes in the downstream edge of the white sand and painted pebble bands will be made to quantify sediment movement during recorded runoff events. 


\section{REFERENCES}

Colton, D., 1999. A series of low-altitude aerial radiological surveys of selected regions within areas 3, 5, 8, 9, 11, 18, and 25 at the Nevada Test Site. DOE/NV/11718-362, prepared for the U.S. Department of Energy, Nevada Operations Office by Bechtel Nevada.

NNSA/NSO, 2009. Corrective Action Decision Document/Closure Report for CAU 370: T-4

Atmospheric Test Site, Nevada Test Site, Nevada, Rev. 0, May 2009 